\title{
Factors Affecting Cattle Prices During Year-End Holiday Season
}

\author{
Sudi Nurtini \\ Department of Livestock Sosio- \\ Economics Faculty of Animal Science. \\ Universitas Gadjah Mada \\ Yogyakarta, Indonesia \\ nurtini@ugm.ac.id
}

\author{
Endang Baliarti \\ Department of Animal Production \\ Faculty of Animal Science \\ Universitas Gadjah Mada \\ Yogyakarta, Indonesia \\ bali_arti@ugm.ac.id
}

\author{
Vinsky Maulana \\ Department of Livestock Sosio- \\ Economics Faculty of Animal Science \\ Universitas Gadjah Mada \\ Yogyakarta, Indonesia \\ vinsky_205@yahoo.co.id
}

\begin{abstract}
This study was to determine the factors that affect the cattle prices during the year-end holiday season in Yogyakarta, Indonesia. The study used 266 cattle transacted at Ambarketawang Animal Market and Mancasan Slaughterhouse in Yogyakarta, Indonesia. This research was carried out using a survey method and direct observations with prepared questionnaires. The data obtained were analyzed using a multiple regression analysis. The dependent variable was cattle price per head that successfully had been transacted at Ambarketawang Animal Market and Mancasan Slaughterhouse in Yogyakarta during the 2016 year-end holiday season. The independent variables were the live weight estimation, age estimation, number of cattle slaughtered in the slaughterhouse, moment, sex, breed, and location of transaction. The results showed that the independent variables, namely the live weight estimation, age estimation, number of cattle slaughtered in the slaughterhouse, moment, sex, breed, and location of transaction showed a very significant effect on cattle price per head. Partially, live weight estimation, moment, and sex showed a positive and very significant effect on cattle price per head. It can be concluded that cattle price per head will increase if the live weight estimation is higher during the year-end holiday season, and the sex is male (bull).
\end{abstract}

Keywords-age estimation, breed, fluctuations in cattle price, holiday season, live weight estimation, sex, the location of transaction, the number of cattle slaughtered

\section{INTRODUCTION}

The marketing of cattle as other agricultural commodities is also experiencing price fluctuations. The fluctuations in cattle prices occur due to the changes in the demand and supply of cattle at the market level [1]. According to [2], cattle prices are primarily resulted from the balance of supply and demand for beef. Similarly, in Indonesia, the price of cattle is not only influenced by the demand and supply of beef but also by socio-cultural factors such as the number of demand for beef, especially during religious festivities and other celebrations during a holiday. Data taken from [3] showed that the significant increase in beef prices occurs during the period of national religious holidays. For at least the last four years, the highest price of beef has occurred during the period of national religious holidays, especially during Eid al-Fitr day and other holidays. This is because during the holiday season, the number of tourists coming to Yogyakarta increases so that the demand/consumption of beef in tourist destinations also goes up. In fact, Yogyakarta is the second tourist destination after Bali. This condition will indirectly lead to the increase in the price of cattle as well.
This research was expected to supply empirical data about beef cattle prices so that information about factors that cause the fluctuations in the beef cattle prices is well provided.

\section{METHODS}

The research was conducted at Mancasan Slaughterhouse and Ambar Ketawang Animal Market, Yogyakarta, Indonesia during the 2016 year-end holiday season. The materials used in this study were 266 cattle transacted at Ambarketawang Animal Market and Mancasan Slaughterhouse, Yogyakarta, Indonesia. The data collected were about live weight estimation, age estimation, the number of cattle slaughtered, moment, sex, breed, and location of transaction

The research instruments were questionnaires. The weight of cattle was measured using $100 \mathrm{~cm}$ butterfly tape measure with the scale of $1 \mathrm{~mm}$.

\section{A. The Body Size Measurement of Cattle}

The chest girth size of cattle is the circumference measured at the back of the shoulder bone or on the third to fourth ribs. The chest girth was measured using a measuring tape. The body length measurement used in this research was the absolute body length measured from the front end of the shoulder bone (Tubercullum humeralis lateralis) to the sitting bone (Tuberculum Ischiadium). The modified Lamborne formula for Indonesia was used to estimate the live weight of the cattle [3]:

$$
\text { Body Weight }=\frac{(\mathrm{CG})^{2}+\mathrm{BL}}{10840}
$$

$\mathrm{CG}=$ Chest Girth

$\mathrm{BL}=$ the Body Length

\section{B. Data Analysis}

According to [4], multiple regression analysis was used to identify the factors that could influence the fluctuations in cattle prices during the 2016 year-end holiday season.

$$
\begin{aligned}
& \mathrm{Y}=\mathrm{a}+\mathrm{b}_{1} \mathrm{X}_{1}+\mathrm{b}_{2} \mathrm{X}_{2}+\mathrm{b}_{3} \mathrm{X}_{3}+\mathrm{b}_{4} \mathrm{D}_{1}+\mathrm{b}_{5} \mathrm{D}_{2}+\mathrm{b}_{6} \mathrm{D}_{3} \\
& +\mathrm{b}_{7} \mathrm{D}_{4}+\mathrm{e} \\
& \mathrm{Y}=\text { Cattle price }(\mathrm{Rp} / \text { head }) \\
& \mathrm{a}=\text { Constant } \\
& b_{1}, b_{2}, b_{3}, b_{4}, b_{5}, b_{6}, b_{7}=\text { Regression coefficients } \\
& \mathrm{X}_{1}=\text { Estimated live weight }(\mathrm{kg}) \\
& \mathrm{X}_{2}=\text { Estimated age (18 and } 36 \text { months) } \\
& \mathrm{X}_{3}=\text { The number of cattle slaughtered (head) } \\
& \mathrm{D}_{1}=\text { Moment } \\
& \mathrm{D}_{1}=0 \text {, if not Holiday }
\end{aligned}
$$




$$
\begin{gathered}
\mathrm{D}_{1}=1 \text {, if holiday } \\
\mathrm{D} 2=\text { sex } \\
\mathrm{D}_{2}=0 \text {, if female } \\
\mathrm{D}_{2}=1 \text {, if male } \\
\mathrm{D}_{3}=\text { breed } \\
\mathrm{D}_{3}=0 \text {, if } \mathrm{PO} \\
\mathrm{D}_{3}=1 \text {, if } \mathrm{PO} \text { crossbred } \\
\mathrm{D}_{4}=\text { Location of transaction } \\
\mathrm{D}_{4}=0 \text {, if in the slaughterhouse } \\
\quad \mathrm{D}_{4}=1 \text {, if in the Animal Market } \\
\mathrm{e}=\text { Error }
\end{gathered}
$$

The data were analyzed using multiple linear regression analysis with the help of SPSS 16.0 for windows.

\section{RESULTS AND DISCUSSION}

\section{A. Factors Assumed to Affect the Price of Cattle}

\section{1) Live weight estimation}

According to [5], cattle weight has a significant effect on cattle prices. The rise in cattle weight can increase the price, but the price per head can fall at certain point. In Indonesia, prices in the transaction of cattle are carried out per head of cattle, not per kg of live weight. Nonetheless, the transaction price is based on the estimated live weight and percentage of carcass produced. Live weight is an important factor to determine cattle prices. Cattle with more live weight will have a relatively higher price than those with less live weight.

\section{2) Age estimation}

According to [6], the age estimation of cattle is determined by observing the change of deciduous teeth (milk teeth or baby teeth) into permanent incisors. If the cattle are old enough and the teeth are all permanent, some of the grinding areas are observed. This estimation is based on the calculation that when a pair of milk teeth has changed, the cattle is about 1 to 1.5 years old. If two pairs of (four) incisor teeth change and have grown perfectly, the cattle is about 2 to 3 years old. Then if three pairs of (six) incisor teeth change, the cattle is 4 to 4.5 years old.

It has been stated by [7] that the increasing age of cattle is in line with the increase in the live weight. Thus, the more mature the cattle are, the higher the carcass weight will be. When the age is older and the weight increases, the carcass weight will increase more than the non-carcass weight.

\section{3) The number of cattle slaughtered in the slaughterhouse}

The number of cattle that are slaughtered reflects the demand for beef which indirectly reflects the need for cattle in an area. According to [8], the demand for a product affects the price of it. The higher the demand, the higher the price will be.

\section{4) Moments}

Cattle prices could be influenced by moments that intersect with religious festivals and holidays. Yogyakarta which is a tourist destination is expected to have a high demand for beef during the holidays. Religious festivities become important moments for cattle beef farmers. The high demand for beef during religious festivities is an opportunity to get more profit for the farmers. The change in the level of demand in certain moments will affect the price of cattle. As reported by [5], the price of cattle at the auction of cattle in Kansas varies at certain hours. In the last quarter (the fourth quarter/after 8 p.m.), the price of cattle per head drops significantly. The drop in the price towards the end of the auction is consonant with the findings of research conducted by [9] stating that this is because many potential buyers have left, or in other words, the demand decreases.

\section{5) Sex}

The sex of cattle can show a difference in the rate of growth in which male livestock can grow faster than the females [7]. Production performances are influenced by their sex. According to [10], male cattle have higher production performances (body weight gain, dry matter consumption, and feed use efficiency) and physiological status (body temperature, respiration, and pulsus) than female livestock.

\section{6) Breed}

The breed of cattle affects the fluctuations of their prices. Those with fast growth and with economical maintenance cost increase in price. On the contrary, those with slow growth and with big maintenance cost will make an opposite effect. Traditional Indonesian cattle farmers prefer Simmental-Ongole (SimPO) crossbred or LimousinOngole (LimPO) crossbred because they think that crossbred cattle grow faster, so the weight is greater.

\section{7) The location of transaction}

The transaction price of a product is affected by the demand and supply of it. Cattle transactions in Yogyakarta can take place in animal markets or in slaughterhouses. A research conducted by [11] in Southeast Aceh Regency found out that cattle prices outside animal markets were higher than that in animal markets.

\section{B. Factors Affecting the Fluctuations in the Price of Cattle}

The results of the Multiple Regression Analysis are shown in Table 1.

Table 1. The Results of the Multiple Regression Analysis

\begin{tabular}{lcc}
\hline \multicolumn{1}{c}{ Variables } & $\begin{array}{c}\text { Regression } \\
\text { Coefficient }\end{array}$ & Significance \\
\hline $\begin{array}{l}\text { Constant } \\
\text { Estimated live weight } \\
\left(\mathrm{X}_{1}\right)\end{array}$ & 0.025 & 0.962 \\
$\begin{array}{l}\text { Estimated age }\left(\mathrm{X}_{2}\right) \\
\text { The number of cows } \\
\text { slaughtered }\left(\mathrm{X}_{3}\right)\end{array}$ & $-0.046^{*}$ & 0.000 \\
Moment $\left(\mathrm{D}_{1}\right)$ & 0.190 & 0.794 \\
Sex $\left(\mathrm{D}_{2}\right)$ & $0.428^{*}$ & 0.823 \\
Breed $\left(\mathrm{D}_{3}\right)$ & $1.739^{*}$ & 0.391 \\
\hline
\end{tabular}

$\mathrm{R}^{2}$ adjusted $=0.931$

$\mathrm{F}=512.988^{* *}$

$* \mathrm{P}<0.01$

Table 1 shows that the value of adjusted R2 is 0.931 . It indicates that $93.10 \%$ of the variance of the fluctuations in 
the price of cattle during the year-end holiday season is influenced by the estimated live weight of cattle (X1), estimated age (X2), number of cattle slaughtered (X3), moment (D1), sex (D2), breed (D3) and location of transaction (D4). As for the rest, 6.90\% is influenced by variables outside the model. The results of multiple regression analysis show that the fluctuations in cattle prices during the year-end holiday season can all be explained and is very significant $(\mathrm{P} \leq 0.01)$. Using the estimated live weight of cattle (X1), estimated age (X2), number of cattle slaughtered (X3), moment (D1), sex (D2), breed (D3) and location of transaction (D4). Partially, the estimated life weight of cattle (X1), moment (D1), and sex (D2) show a positive and very significant influence $(\mathrm{P} \leq 0.01)$ on the fluctuations of cattle prices during the yearend holiday season. The results of this research confirms the former findings of [12] who stated that more live weight of cattle will give a positive influence on the cattle price per head and [5] also reported that weight, health, lot size, pregnancy, grade, dressing percent, breed, time of sale, and market location are found important to affect the difference in cattle prices.

Research conducted by [13] showed that the weight of young cattle would increase fast and steadily until puberty, and ultimately, there was no increase in the body weight after reaching adulthood. If the weight was still increasing, it was only caused by the accumulation of fat under the skin (subcutan) and the abdominal fat (abdomen) not an increase in bones and meat so that the weight of the meat did not increase. This condition was very well understood by cattle traders, resulting in the decrease in cattle prices if the cattle reached the age of 3 as shown in this study. Thus, although the transaction price of cattle was positively influenced by the live weight estimation, it only worked at a certain age. Moreover, the results of this research showed that the cattle traded to be slaughtered are at the age of 3 on average.

According to [14], the factors used by cattle traders to determine cattle weight or carcass weight produced by cattle are highly accurate.

Table 1 shows that the dummy moment has a positive effect on the price of cattle.

The equation of the multiple regressions for the price of nonholiday moments is:

$\mathrm{Y}=0.025+0.046 \mathrm{X}_{1}-0.002 \mathrm{X}_{2}+0.019 \mathrm{X}_{3}+1.739 \mathrm{D}_{2}+0.217$

$\mathrm{D}_{3}+0.024 \mathrm{D}_{4}$

The equation of the multiple regressions for the price of holiday moments is:

$\mathrm{Y}=0.453+0.046 \mathrm{X}_{1}+-0.002 \mathrm{X}_{2}+0.019 \mathrm{X}_{3}+1.739 \mathrm{D} 2+$ $0.217 \mathrm{D}_{3}+0.024 \mathrm{D}_{4}$

Sex can make different growth rates where bulls usually grow faster than cows [7]. Since production performance is influenced by the sex of cattle, the cattle price per head is also affected by sex.

According to [10], male cattle showed higher production performance (body weight gain, dry matter consumption and feed efficiency) and physiological status (body temperature, respiration and pulsus) than female cattle. The difference in body composition between the sexes is mainly affected by genital steroids. Even though they are of the same body weight, the amount of fat in cows, sheep, and pigs varies. In cattle, the amount of fat in cows is larger than that of castrated males, and both are larger than bulls (7).

Table 1 shows that the dummy sex has a positive effect on the cattle prices.

The equation of the multiple regressions for the cow prices is:

$\mathbf{Y}=0.025+0.046 \mathrm{X}_{1}-0.002 \mathrm{X}_{2}+0.019 \mathrm{X}_{3}+0.428 \mathrm{D}_{1}+0.217$ $\mathrm{D}_{3}+0.024 \mathrm{D}_{4}$

The equation of the multiple regressions for the price of bulls is:

$\mathbf{Y}=1.764+0.046 \mathrm{X}_{1}-0.002 \mathrm{X}_{2}+0.019 \mathrm{X}_{3}+0.428 \mathrm{D}_{1}+0.217$ $\mathrm{D}_{3}+0.024 \mathrm{D}_{4}$

\section{CONCLUSION}

The higher the live weight, the higher the price of cattle per head of a certain age ( 3 years old) is. During the year-end holiday season, the price of cattle is higher than that found in the non-holiday moments. Bulls have higher prices than cows. It is suggested that if the producers (farmers) want to optimize the price of cattle they sell, they should attend the maximum live weight at a certain age, the sex of the cattle, the moment of transaction.

The current agricultural development strategy has not placed animal protein sources as a strategic commodity yet. It is high time for the Government to put animal protein sources such as beef cattle as a potential food source to be developed.

\section{REFERENCES}

[1] K. Grier, Cattle Price Determination in Ontario, George Moris Centre, 2007.

[2] V. Maulana, "Faktor-faktor yang diduga mempengaruhi fluktuasi harga sapi pada liburan akhir tahun di rumah potong hewan Mancasan Sleman," Skripsi, Fakultas Peternakan UGM, Yogyakarta, 2017, Unpublished.

[3] D. Gudjarati, Ekonometrika Dasar, Penerbit Erlangga, Jakarta, 2006.

[4] J. Mintert, J. Blair, T. Schroeder, and F. Brazle, "Analysis of factors affecting cow auction price differentials," Southern Journal of Agricultural Economics, pp. 23-29, December 1990

[5] R. D. Frandson, W. L. Wilke, and A. D. Fails, Anatomy and Phisiology of Farm Animals, Seventh Edition, Wiley-Blackwell, A John Wiley \& Sons, Inc., Publication, 2009.

[6] Soeparno, Ilmu dan Teknologi Daging, Edisi IV, Gadjahmada University Press, Yogyakarta, 2005.

[7] R. S. Pindyck and D. L. Rubinfeld. Microeconomics, Fourth Edition, Prentice All International, Inc., Upper-Saddle River, New Jersey 07458, 1998

[8] S. T. Buccola, "Price trends at livestock auctions," Am. J. Agr. Econ. 64, pp. 63-69, 1982.

[9] Padang and Irmawaty, "Pengaruh jenis kelamin dan lama makan terhadap berat dan persentase karkas kambing kacang," J. Agri. vol. 3 no. 1, Juny 2007.

[10] M. Srafaga, Hasnudi and E. H. Kardhinata. Analisis pemasaran ternak sapi di Kabupaten Aceh Tenggara. Agrica Journal of Agribusiness Agriculture, vol. 5 no.1, April 2012.

[11] G. W. Jesse, G. B. Thomson, J. L. Clark, H. B. Hedrick and K. G. Weimer, "Effect of ration energy and slaughter weight on composition of empty body and carcass gain of cattle," J. Anim Sci, vol. 43(2), pp. 418-425, August 1976 
[12] Manurung, "Analisis ekonomi uji ransum berbasis pelepah daun sawit, lumpur sawit dan jerami padi fermentasi dengan phanerochate chysosporium pada sapi peranakan ongole," Skripsi, Fakultas Pertanian, Universitas Sumatera Utara Medan, 2008, Unpublished.

[13] S. Nurtini, E. Baliarti and D. C. Chotimah. "Model of carrying on trade of beef cattle at slaughterhouse in Yogyakarta, Indonesia," Indian J. Anim. Res. 51 (3), pp. 613-615, 2017.

[14] Sugiarto, T. Herlambang, Brastoro, R. Sudjana, S. Kelana, Ekonomi Mikro, Sebuah Kajian Komprehensif, Penerbit PT Gramedia Pustaka Utama, Jakarta, 2005. 